\title{
An investigation on Mongolian students' college English learning motivation and methods of encouragement ${ }^{1}$
}

\author{
Fan Xiaoming*
}

\begin{abstract}
This paper, enlightened by the researches of learning motivation, focuses on the methods of encouraging Mongolian students' college English learning motivation with the aid of statistical analysis and interviewing. The result of this investigation illustrates that both Mongolian students and Han students agreed that environmental and teachers' factors had great influence on their college English learning motivation though there exist differences in college English learning motivation between the two groups of students. Therefore, finding out appropriate methods of encouragement should effectively improve English teaching for Mongolian students.
\end{abstract}

Keywords: Mongolian Students; College English learning motivation; methods of encouragement.

\section{Uma investigação sobre motivação de aprendizagem e métodos de incentivo de Inglês em relação a universitários Mongolianos}

\section{Resumo}

Este artigo, inspirado nas pesquisas de motivação de aprendizagem, centra-se nos métodos de incentivo de estudantes universitários Mongolianos em relação à motivação de aprendizagem de Inglês com a ajuda de análise estatística e entrevistas. O resultado desta investigação ilustra que tanto os estudantes da Mongólia quanto estudantes de Han concordaram que os fatores ambiental e relativos aos professores tiveram grande influência sobre sua motivação para a aprendizagem de Inglês na universidade, embora existam diferenças entre os dois grupos de estudantes. Portanto, descobrir métodos adequados de incentivo deve efetivamente melhorar o ensino de Inglês para estudantes da Mongólia.

Palavras-chave: Estudantes da Mongólia; Motivação de aprendizagem de inglês na universidade; métodos de incentivo.

\section{Introduction}

Motivation is one of the key elements in foreign Language learning and teaching researches. Learning motivation affects the students' learning interest, and with increased interest, students language acquisition will increase. That is why many researches have been conducted on learning motivation and advocated that language teaching should be tailored to different learner groups.

In Inner Mongolia, there are primarily two English learner groups in colleges and universities. The major group is the Han people, and the Mongolians are the minor group who are almost beginners in college English learning. Therefore
College English teaching has a different meaning to the two groups. In order to find out the differences and tailor the English teaching to the Mongolian ethnic minority group, some teachers and researchers have studied Mongolian students' English learning motivation for several years; however, after searching CJFD (Chinese Journal Full-text Database) our research team found that only one paper by Liu $\operatorname{Bin}^{[3]}$ is on the investigation of Mongolian students' English learning motivation. The result of Liu Bin's investigation tells that $85 \%$ of them disagree or strongly disagree that they want to read English books and watch English movies; almost all the Mongolian students have no desire to know about the culture of English countries. $47.2 \%$ and $28.4 \%$ of the

*Endereço eletrônico: fanxiaoming@sina.com 
Mongolian college students agree or strongly agree that they have little interest in English learning and $46.2 \%$ and $23.8 \%$ of them agree or strongly agree that they are absent-minded in class and some of them even don't want to go to English class." The reasons, in her investigation, are lack of Mongolian English teachers "... and above all the negative transfer of the two languages---Mongolian and Chinese, which makes English learning all the more difficult for Mongolian students. Mongolian and Chinese grammar and sentence structures are both quite different from English, so Mongolian students have more difficulties in learning English and this accounts for their little interest in English learning." [3]

Focusing on the methods of encouraging Mongolian students English learning motivation, our research team partly agreed to Liu's investigation results and conducted our own investigation from different aspects and in comparison with Han students.

\section{Investigation}

With three monitors' help, the investigation was conducted from 8th April to 10th April, 2012. Participants of the survey were 142 junior college students from Inner Mongolia University of Technology. Altogether 142 copies were issued and 130 valid copies were obtained, this provided a valid return rate of $91.5 \%$. Among these 130 students, 68 students were from the classes for minority preparatory college students (Group 2) and 62 were from normal classes (Group1).

\section{Questionnaire}

Having studied the classical motivation models and expanded motivation models ${ }^{[4]}$, our research team conducted an interview in which there were 13 students from both groups who were asked to make a list of their English learning motivations. Based on the interview results, we designed our own questionnaire. The questionnaire consists of two sections, section A focused on motivation types and section $\mathrm{B}$ on factors of encouragement.

There are 9 questions in section A. The first one is a multiple-choice question with five options, and the rest need to be answered on the five-points Likert scale. Section B of the questionnaire shows the 20 items of the methods of encouragement divided into four groups of factors. (See the Appendix)

\section{Data analysis Analysis of Section A}

The first question is "You often take English learning as __. The options are "a hobby, a communication tool, increasing your spectrum of enjoyment, accumulation of culture, a compulsory course ". (Table 1) It aims to discover the college students' English cognition by analyzing their answer distribution, for the learners' understanding of the target language is the condition precedent for cultivating learning motivation.

Table 1 Cognition to English

\begin{tabular}{|l|c|c|c|c|c|}
\hline $\begin{array}{c}\text { Group } \\
\text { data } \\
\text { options }\end{array}$ & $\mathrm{H}$ & $\mathrm{T}$ & $\mathrm{E}$ & $\mathrm{A}$ & $\mathrm{C}$ \\
\hline Group2 & $6.7 \%$ & $47.1 \%$ & $8.8 \%$ & $51.5 \%$ & $39.1 \%$ \\
\hline Group1 & $43.8 \%$ & $42.2 \%$ & $8.1 \%$ & $50 \%$ & $3.5 \%$ \\
\hline $\mathrm{Z}$ score & 4.01 & 1.01 & 0.12 & 0.56 & 3.56 \\
\hline $\mathrm{Z}_{\mathrm{a} / 2}=1.96$ & $\mathrm{~S}$ & $\mathrm{In}$ & $\mathrm{In}$ & $\mathrm{In}$ & $\mathrm{S}$ \\
\hline
\end{tabular}

( $\mathrm{H}=$ hobby; $\mathrm{T}=$ communication tool; $\mathrm{E}=$ enjoyment; $\mathrm{A}=$ accumulation of culture; $\mathrm{C}=$ compulsory course; $\mathrm{S}=$ significant; In=insignificant) 
As shown in Table 1, in order to know whether the two groups have significant differences in English cognition, $\mathrm{X}^{2}$ test was applied. From the $\mathrm{Z}$ score, it can be said that both Group 2 and Group 1 students have the same idea that the purpose of English learning is to obtain a communication tool and an accumulation of culture. A small segment in both groups regarded it as entertainment. While in terms of "a hobby" and "a compulsory course", there are significant discrepancies between the two groups ( $\mathrm{Z}$ score are 4.01 and 3.56, which are higher than the critical value $\mathrm{Za} / 2=1.96$ ). As can be seen $43.8 \%$ students in Group1 believed that English learning is led by interest compared with the percentage of Group2 students' $6.7 \%$. In addition, 39.1\% students in Group2 maintained that they often related learning English with a course that must be learned. On the contrary, the percentage from the students in Group1 is only $3.5 \%$, which attracted our attention. In order to find out the reason, we interviewed 5 students from Group 1 and 8 students from Group 2. The answers from Group 1 were that English learning reminded them of "English songs, movies, stories, magazines, "or "talking with foreigners "or "understanding the English instructions of the goods made abroad". The answers from Group 2 focused on "examinations, certificates" or "it's mainly a course". According to the answer distribution above, the conclusion may be drawn that Group 2 students have known the basic function of English learning; however, in their living environment, they use Mongolian much more than Chinese and a few of them never think of English at all. In fact, most of the students in Group2 were from the remote countryside and didn't come in contact with anything related to English in their daily life. Those who were from cities affected by Chinese interaction had the same understanding as the Han students. As a whole body Group 2 students have less interest in college English learning than Group 1 mostly because English is their third language and much less familiar to them.

The rest of the questions in section $\mathrm{A}$ centered around "why do you study English?" There are 8 questions to be answered on a five-point Likert scale ranging from "completely disagree"(1), "disagree"(2),"partly agree"(3), "agree"(4)", completely agree"(5). SPSS11.0 was applied to process the data to measure the central tendency described by mean, median, mode, and the dispersion by standard variation and variance. In this case, the mode is three, so if the value of the mean is greater than three, it means that the students agree or partly agree they learn English by this kind of motivation, and thus less than three means they disagree. The result is in Table2.

Table 2 the Motivation Items

\begin{tabular}{|l|l|l|l|l|l|l|l|l|}
\hline $\begin{array}{l}\text { Questions } \\
\text { data }\end{array}$ & \multicolumn{2}{l}{ Group1 } \\
\cline { 2 - 10 } & mean & median & mode & variance & mean & Median & mode & variance \\
\hline Q1: having interest (a hobby) & 4.11 & 4.00 & 5 & .795 & 3.12 & 3.00 & 3 & 1.397 \\
\hline Q2: enjoying English movies... & 3.89 & 4.00 & 5 & .756 & 2.65 & 3.00 & 3 & 1.482 \\
\hline $\begin{array}{l}\text { Q3: a symbol of high-quality/ } \\
\text { knowledge }\end{array}$ & 2.65 & 3.00 & 3 & .782 & 4.25 & 4.00 & 5 & .764 \\
\hline Q4: admired by peers & 2.88 & 3.00 & 3 & 1.328 & 4.43 & 5.00 & 5 & .593 \\
\hline Q5: going abroad & 2.75 & 3.00 & 3 & 1.030 & 2.29 & 2.00 & 3 & 1.430 \\
\hline Q6: communicating with foreigners & 3.42 & 4.00 & 5 & 1.752 & 2.60 & 3.00 & $3 \& 2$ & 1.744 \\
\hline Q7: passing exams & 4.62 & 5.00 & 5 & .490 & 4.73 & 5.00 & 5 & .486 \\
\hline Q8:getting certificate for a good job & 4.31 & 5.00 & 5 & .560 & 2.26 & 2.00 & $3 \& 1$ & 1.025 \\
\hline
\end{tabular}


From Table 2, it can be seen that there are five modes valued 5 , which means most students in Group1 choose "completely agree" to Q1, Q2, Q6, Q7,Q8. And from the values of the corresponding variance $(\mathrm{Q} 1=.795, \mathrm{Q} 2=.756, \mathrm{Q} 7=.490, \mathrm{Q} 8=.560)$, it can be said that the degree of dispersion is comparatively small. This indicates most students in Group 1 take interest, entertainments and passing all kinds of exams as their motivations of learning English. The variance of Q6 (1.752) is the highest one in the table, which indicates some students within the group had quite different ideas about "communicating with foreigners ". In fact, the students from the countryside have few chances to talk with foreigners except those who have English classes taught by foreign teachers.

Compared with Group 1, the students in Group 2 held the opposite ideas to most questions except the one, passing exams, which may be the most basic motivation for students around the world. Q1 and Q2 are related to each other because the students have interest in English partly due to the language itself (pronunciation, grammar etc.), and mostly for enjoying all kinds of works in English. Group2 students' choices to these two questions are almost in accordance with each other. Q6 and Q8 both have two modes which means the numbers of the two choices are the same. To be specific, the mode of Q6 tells the number of students who think talking with foreigners may partly be the motivation is the same as that of "completely disagree". The reason for such a great difference was found from the post-interview, in which the Mongolian students told us that they don't use Chinese very often, much less English which is so far away from them. This can also explain Q8, most Mongolian students are weak in English; therefore, they may never expect to pass Band- 4 or Band- 6 to get the certificate even though they have known that will give them a good job in the future. In recent years, some Mongolian college students who come from "Experimental Classes", in which they have the same requirements as the Han students when they take part in the college entrance Horizontes, v. 34, n. 1, p. 113-122, jan./jul. 2016 examinations, have better performance in English. However, there are few students in this category.

Q3 and Q4 show that Group 2 students have more sense of self-pride than Group 1, for most of them (mode=5, variance $=.764)$ strongly agree that English represents being well-educated. Especially Q4 (mode $=5$, variance $=.593$ ) indicates that almost all of them have the same idea that learning English well results in being admired by peers including classmates and friends in their hometown. Besides the factor of national personality, their living environment also contributes to this outcome. Most Mongolian students come from countryside where people communicate and care more about friends or neighbors; therefore, they care more about others' opinion of them. They think that knowing English will be admired by others or provides status.

From the value of the mode of Q5, Group 2 students are in accordance with Group1 in terms of going abroad. Nevertheless, the degree of their negative attitudes is different. Group 1, with the mean value 2.75 and variance 1.030 , show more tendency to "partly agree"; while Group 2, with the mean value 2.29 , the median 2.00 and variance 1.430 , is closer to "disagree". This is in agreement with the result of the post-interview. Students in both groups said that there were few chances for them to go abroad from Inner Mongolia. Especially the Mongolian students, they preferred to go to Japan, so they thought English was not very useful.

From the data analysis of section A, it may be implied that Group 2 students don't study English for interest; they learn English mainly for passing examinations, and due to their poor English foundation they don't expect to get certificates for CET4 and CET6TPET, GRE or even TOFEL to aid them in finding a good job or going abroad. Group 2 students care more about praise from others and they hope to be admired by others.

\section{Analysis of Section B}

There are 20 items of methods of 
encouragement divided into four groups of factors: environment factors, teacher factors, feedback factors, reality factors in Section $B$ of the questionnaire. The choice is either "Y"(yes) or "N"(no); therefore, the data of this section was processed by Excel 2003 in the form of percentage to calculate the rate of "Yes", which means the student may be encouraged to learn English in this way. The items are in Table 3 and the results are in Table 4.

Table 3 Encouragement Methods

\begin{tabular}{|c|c|c|}
\hline \multicolumn{2}{|l|}{ Questions } & Explanations \\
\hline \multirow{5}{*}{$\begin{array}{l}\text { Environmental } \\
\text { Factors }\end{array}$} & QB1 & Having chances to use English in daily life \\
\hline & QB2 & English classes centered around listening and speaking training \\
\hline & QB3 & Opening English courses taught by foreigners and joining English corner \\
\hline & QB4 & Providing English programs frequently \\
\hline & QB5 & Enjoying English movies and music together \\
\hline \multirow{5}{*}{$\begin{array}{l}\text { Feedback } \\
\text { Factors }\end{array}$} & QB6 & Getting praise from teachers for my English progress \\
\hline & QB7 & Improving English level during competition \\
\hline & QB8 & Getting care and supports from parents \\
\hline & QB9 & Getting praise from classmates \\
\hline & QB10 & Getting objective evaluation from teachers \\
\hline \multirow{5}{*}{$\begin{array}{l}\text { Teacher } \\
\text { Factors }\end{array}$} & QB11 & The teacher often uses examples from daily life to teach English \\
\hline & QB12 & The teacher cares the students school lives \\
\hline & QB13 & The teacher sets study object and help students fulfill them \\
\hline & QB14 & The teacher can always reply the students' questions \\
\hline & QB15 & The teacher often talks on learning approaches or skills \\
\hline \multirow{5}{*}{$\begin{array}{l}\text { Reality } \\
\text { Factors }\end{array}$} & QB16 & Obtaining a diploma by passing college English examinations \\
\hline & QB17 & English is regarded as a standard to select graduates by employer \\
\hline & QB18 & Obtaining credit scores and scholarship by passing CET4, CET6, PETS etc \\
\hline & QB19 & Getting chances of going abroad by having high English \\
\hline & QB20 & Having many admirers and becoming self-confident \\
\hline
\end{tabular}

Table 4 Encouragement Methods Results

\begin{tabular}{|c|c|c|c|c|}
\hline $\begin{array}{l}\text { Encouragement } \\
\text { factors }\end{array}$ & $\begin{array}{l}\text { Encouragement } \\
\text { methods }\end{array}$ & $\begin{array}{l}\text { Rate of "yes" } \\
\text { (Group2) }\end{array}$ & $\begin{array}{l}\text { Rate of "yes" } \\
\text { (Group1) }\end{array}$ & Rank \\
\hline \multirow{5}{*}{$\begin{array}{l}\text { Environmental } \\
\text { factors }(35.2 \%)\end{array}$} & QB1 & $76.4 \%$ & $80.6 \%$ & \multirow[t]{5}{*}{1} \\
\hline & QB2 & $66.2 \%$ & $61.3 \%$ & \\
\hline & QB3 & 58.85 & $59.7 \%$ & \\
\hline & QB4 & $52.9 \%$ & $53.2 \%$ & \\
\hline & QB5 & $79.4 \%$ & $80.6 \%$ & \\
\hline \multirow{3}{*}{$\begin{array}{l}\text { Feedback } \\
\text { Factors }(19.7 \%)\end{array}$} & QB6* & $48.5 \%$ & $32.3 \%$ & \multirow[t]{3}{*}{3} \\
\hline & QB7 & $54.4 \%$ & $54.8 \%$ & \\
\hline & QB8 & $28 \%$ & $29.0 \%$ & \\
\hline
\end{tabular}




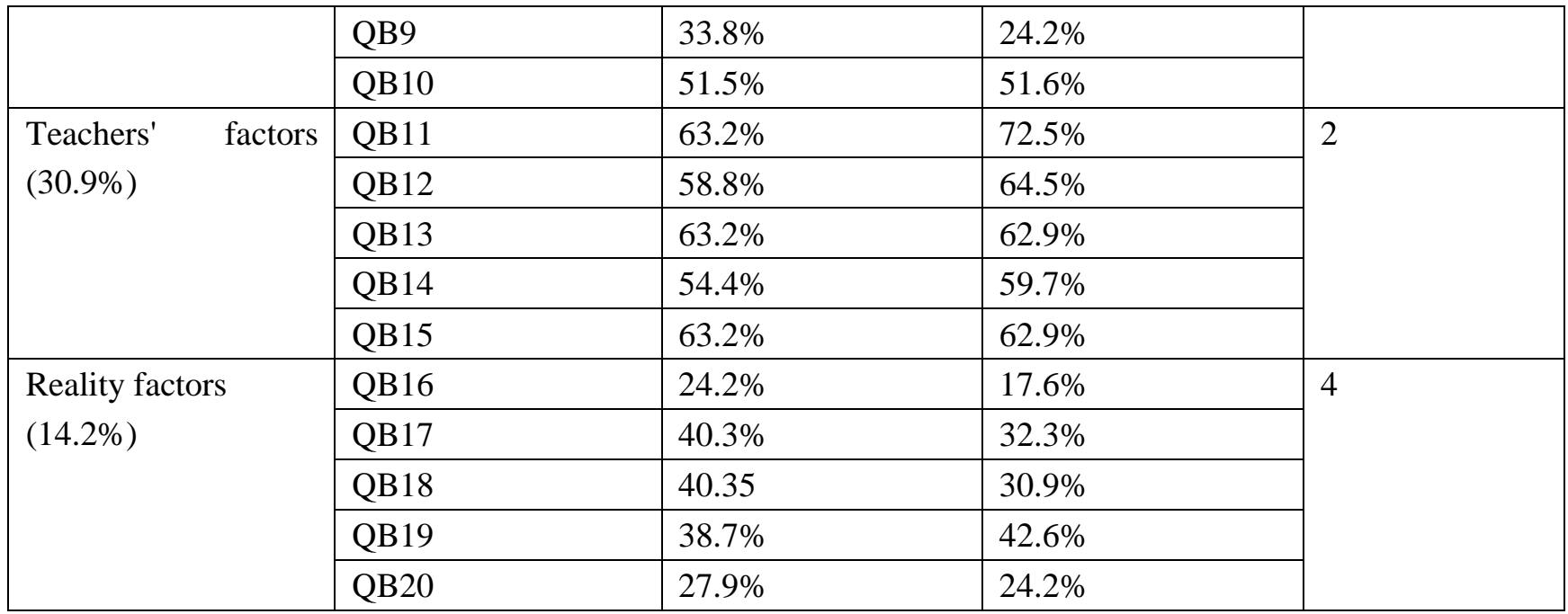

* $X^{2}$ test was applied but there was no significant statistical discrepancy between the two groups except QB6.

From Table 4, it can be seen that environmental factors rank the first (the average percentage is $35.2 \%$.), the teachers' factor second (30.9\%), feedback factors (19.7\%) third and reality factors the last (14.2\%).

That students' emphasis on environmental factors actually reflects the practicality of learning English works as the strongest motivation and students are eager to have chances to use English in real life. However, they seem to have English classes for nothing but all kinds of exams. Maybe that's the biggest barrier to English learning in Inner Mongolia.

Since there is no positive environment factor to drive them to learn English, the teachers' factors become very important to the students. One recent study on "good English teachers' professional qualities" showed that the professional profile for effective university EFL teachers consists of four related dimensions: English language pedagogical content competence, view of the foreign language teaching profession and professional ethics, view of foreign language teaching and learning, and view of language teacher learning and development. ${ }^{[4]}$ In our survey, teachers' factors focused on two aspects: teachers' competence and teachers' attitude toward the students. In other words, students' English learning is motivated by those teachers who have good English language pedagogical competence
(QB13, QB14 and QB15) and professional ethics (QB12). Besides, QB11 reinforces that students have a strong desire to make English learning more practical and useful. QB11 was chosen by the most participants, which indicates teachers should connect the teaching contents with the students' life and make English practical and relevant.

As for feedback factor, there are three points worthy of discussion. QB6 shows statistical discrepancy between the two groups, which again proves that Mongolian students rely much on praise from others, especially the teachers. QB10 and QB6 together indicate feedback from teachers matter significantly to the students, which again shows that teachers' influence on students' English learning is predominant. QB8 makes up the least percentage among the feedback items, and that implies the students don't care much about their parents expectation, thus turning to their parents for help is not a good method of encouragement.

The reality factors here mainly were centered on the practical use of English learning, which, at present, is mostly related to exams. Data shows that most students were indifferent to QB16, because they hated the final examination of college English and some of them hoped to avoid it. This means students are fed up with being forced to learn English, thus also explains that extrinsic motivation works weakly 
compared to intrinsic motivation.

\section{Results and Discussion}

The result of the investigation indicates that students' living conditions have influence on their cognition to English. Most Mongolian students are from countryside, so they take English as a compulsory course rather than a kind of hobby though they have the same idea with the Han students in terms of the function of English.

As for learning motivation, the Mongolian students pride themselves on being a member of English learners and hold the opposite ideas to the Han students in terms of the sense of pride. Therefore, teachers should take this point into their consideration during the process of promoting Mongolian students' English learning motivation. Besides, exams may be and still will be the predominant one in all kinds of learning motivation. However, most Mongolian students don't relate exams to job hunting, which is quite different from the Han students and also not in agreement with the result of Liu Bin's investigation.

The result of the survey on methods of encouragement suggests that teachers need to carefully examine the environmental and teachers' effects on Mongolian students' college English learning in order to effectively encourage the Mongolian students to learn English.

Due to the great influence of environment on language learning, researchers proposed the term "Language immersion", which is a method of teaching a second language in which the target language (or L2) is used as the means of instruction. Unlike more traditional language courses, where the target language is simply the subject material, language immersion uses the target language as a teaching tool, surrounding or "immersing" students in the second language. Today's immersion programs are based on those founded in the 1960s in Canada when middle-income English-speaking parents convinced educators to establish an experimental
French immersion program enabling their children to appreciate the traditions and culture of Frenchspeaking Canadians as well as English-speaking Canadians. Studies suggest that immersion is an effective way to learn foreign languages and early immersion students are more successful in listening and reading proficiency than partial and late immersion students. ${ }^{[5]}$ As adults, college students may have more difficulties with "immersion"; nevertheless, if more chances are available for them to use English, it is more likely to arouse the students' learning interest.

As for the teachers effect, our research team cannot agree with Liu Bin's opinion that " Mongolian English teachers should be cultivated in no time. English teachers should be able to teach English either in Chinese or in Mongolian native language." [3] According to our interview, most Mongolian students preferred Chinese to Mongolian as their teaching language, which was out of our expectation at that time. Then we found the reason that Mongolian students thought Chinese would be more useful in their future work places. Therefore, we put emphasis on teachers' classroom assessment feedback and teachers' guidance. 'Teachers' classroom assessment feedback, together with other elements of a classroom assessment event, influences students' motivation first, and then their achievement. In other words, this external factor--- feedback, is mediated by the internal factor---student motivation, before it has an impact on students' performances and achievement. " [6] In summary, English teachers need to have a clear cognition of their role in the process of motivating students' learning. "It's proved that near-future and future aims can both play important roles in passing an examination and leading students to have lasting interest in learning." ${ }^{[7]}$ With a series of specific objectives, the students' endeavor should become sustainable, and the students should become confident and have interest in learning when they see their improvements. When setting up learning objectives, teachers should make their students understand that it is not easy to learn foreign Horizontes, v. 34, n. 1, p. 113-122, jan./jul. 2016 
language, and it needs a lot of time and effort.

\section{Conclusion}

Although researchers give different opinions as to the division of motivation, one point is constant that English learning is affected not by any single one but by several types working together. Learners may have different motivation at different times or in different situations, which means these types of motivations go along together, stimulate each other and even interchange with each other. Therefore, both intrinsic and integration types of extrinsic motivation should be desirable in English teaching and learning research.

Mongolian students have their own language, culture background and typical living condition. Their English learning is affected by the interaction of many comprehensive factors. We hope that our findings will provide valuable points for further research.

\section{Notes}

1 This paper is supported by provincial government project: Foreign Language Teachers' Professional Development and Evaluation in Inner Mongolian Universities (No. 2012C057).

\section{References}

LING-SHU, Z.; XUE-RONG, F. An Empirical Study of Counter-strategies to Lack of English Learning
Motivation of Inland Tibetan Students----A Case Study of Hunan Vocational College for Nationalities. Journal of Hunan University of Science and Engineering, Xiang, v. 3, p. 223-226, 2008.

XING-YUE, H. A Study of the Motivation Types of the Ethnic University Students.Journal of Kunming University of Science and Technology, Kunming, v. 6, p. 76-81,2009.

BIN, L. An Investigation on the Current situation of the Mongolian College Students' English learning Motivation. Journal of Inner Mongolia University of the Nationalities (Social Sciences), Hohhot, v.3, p. 169-171, 2010.

GARDNER, R; LAMBERT, W. Attitudes and Motivation in Second Language Learning. Rowley, Mass: Newbury House.1972.

SHARP, E. H. Individual Motivation and Parental Influence on Adolescents' Experiences of Interest in Free Time: A Longitudinal Examination. Journal of Youth and Adolescence. EUA, v. 6, p. 3-7, 2006.

XIAOYING, W. Teachers' Classroom Assessment Feedback and Student Motivation: A Literature Review. CELEA Journal(Bimonthly), China, p. 7884, 2006.

KELLY, R. A. and JESSICA, S. J. African American Students at Predominantly White Institutions: A Motivational and Self-systems Approach to Understanding Retention. Educational Psychology Review, EUA, p. 2-5, 2008. 


\section{Appendix}

\section{On Motivation and the Methods of encouragement to College English Learning}

Dear students:

March 27, 2012

The purpose of this study is to learn your motivation and find out the methods to encourage your college English learning, so that the teachers can further improve their teaching. You don't need to write your name on this questionnaire and your answer will be used only for this research, so please tell us your own ideas. Thank you!

\section{Questionnaire A}

Please select the options for following topics according to your own idea:

1. You often take English learning as
A. a hobby
B. a communication tool
C. increasing your spectrum of enjoyment
D. accumulation of culture
E. a compulsory course

2. The main reason for your college English learning is that you are interested in English (pronunciation, grammar, discourse structure, etc.)
A. completely disagree
B. disagree
C. partly agree
D. agree
E. completely agree

3. The main reason for your college English learning is that you like English movies, songs, novels and other works.
A. completely disagree
B. disagree
C. partly agree
D. agree E. completely agree

4. The main reason for your college English learning is that English reflects the high level of one's knowledge of culture.
A. completely disagree
B. disagree
C. partly agree
D. agree
E. completely agree

5. The main reason for your college English learning is to be admired by your peers.
A. completely disagree
B. disagree
C. partly agree
D. agree
E. completely agree

6. The main reason for your college English learning is to have the opportunity to study abroad in the future.
A. completely disagree
B. disagree
C. partly agree
D. agree
E. completely agree

7. The main reason for your college English learning is to communicate with foreigners in the future.
A. completely disagree
B. disagree
C. partly agree
D. agree
E. completely agree

8. The main reason for your college English learning is to pass the exams to get the graduation certificate.
A. completely disagree
B. disagree
C. partly agree
D. agree
E. completely agree

9. The main reason for your college English learning is that to take the English certificate (CET4, CET6, PET, GRE, etc. TOFEL) to find a good job.
A. completely disagree
B. disagree
C. partly agree
D. agree E. completely agree 


\section{Questionnaire B}

Please select Y for "agree" or N for "disagree" to the following topics:

Which of the following conditions can encourage you to learn English?

$\circ \mathrm{Y} \circ \mathrm{N} 1$. I have the opportunity to use English in daily life.

$\circ \mathrm{Y} \circ \mathrm{N} 2$. English classes focus on listening and speaking ability training.

$\circ \mathrm{Y} \circ \mathrm{N} 3$. English classes taught by or English corner held by a native speaker.

$\circ \mathrm{O}$ N 4. Many popular TV programs often broadcasted in English.

$\circ \mathrm{Y} \circ \mathrm{N} 5$. English movies and songs played in class.

$\circ \mathrm{Y} \circ \mathrm{N}$ 6. My English teachers often praise my progress in English.

$\circ \mathrm{Y} \circ \mathrm{N} 7$. I often have opportunities to take part in English contests to improve my English

$\circ \mathrm{Y} \circ \mathrm{N}$. My parents care my English and give me support.

$\circ \mathrm{Y} \circ \mathrm{N}$ 9. My classmates give me high praise for my English learning achievements.

$\circ \mathrm{Y} \circ \mathrm{N}$ 10. My teacher gives me objective evaluation to my English learning.

$\circ \mathrm{Y} \circ \mathrm{N}$ 11. My teacher applies real events as examples to our English classes.

$\circ \mathrm{Y}$ ○ 12. My teacher cares about my college life. (not limited to classroom teaching)

$\circ \mathrm{Y} \circ \mathrm{N}$ 13. My teacher helps me set learning goals regularly and make achievements with the guidance of the teacher.

$\circ \mathrm{Y}$ ○ 14. My teacher can solve my problems in the learning process in time and accurately.

$\circ \mathrm{Y} \quad \mathrm{N}$ 15. My teacher can help me with my English learning methods and skills

$\circ \mathrm{Y} \circ \mathrm{N}$ 16. I cannot get the diploma if I cannot pass the College English test.

$\circ \mathrm{Y} \circ \mathrm{N} 17$. There are more fancy employers who put emphasis on interviewees' English achievements.

$\circ \mathrm{Y} \circ \mathrm{N}$ 18. I can obtain a considerable number of credits and scholarship with the certificates of all kinds English proficiency exams.

$\circ \mathrm{Y} \quad \mathrm{N}$ 19. I can get the chance of studying abroad with better English achievements

oY oN 20. That my peers admire my English makes me very confident.

\section{About the author}

Fan Xiaoming: She is an associated professor, she is working at the Department of College English Teaching \& Research, College of Foreign Languages. Inner Mongolia University of Technology, Hohhot, Inner Mongolia. People's Republic of China. She has accomplished a post-doctoral research at the University of WisconsinMadison, USA.

Recebido em setembro de 2015.

Aprovado em janeiro de 2016. 